Article

\title{
New Lignans from the Leaves and Stems of Kadsura philippinensis
}

\author{
Yu-Chi Lin ${ }^{1,2}$, Yuan-Bin Cheng ${ }^{1,3}$, Chia-Ching Liaw ${ }^{1}$, I-Wen Lo ${ }^{1}$, Yao-Haur Kuo ${ }^{4}$, \\ Michael Y. Chiang ${ }^{5}$, Chang-Hung Chou ${ }^{6}$ and Ya-Ching Shen ${ }^{1, *}$
}

1 School of Pharmacy, College of Medicine, National Taiwan University, 1, Sec. 1, Jen-Ai Rd., Taipei 100, Taiwan; E-Mail: z10108042@email.ncku.edu.tw (Y.-C.L.); jmb@kmu.edu.tw (Y.-B.C.); biogodas@hotmail.com (C.-C.L.); d96423006@ntu.edu.tw (I.-W.L.)

2 Department of Life Sciences, National Cheng Kung University, No. 1 University Road, Tainan 701, Taiwan

3 Graduate Institute of Natural Products, School of Pharmacy, Kaohsiung Medical University, Shih-Chuan 1st Road, Kaohsiung 807, Taiwan

4 National Research Institute of Chinese Medicine, Taipei 112, Taiwan;

E-Mail: kuoyh@nricm.edu.tw

5 Department of Chemistry, National Sun Yat-sen University, 70, Lien-hai Road, Kaohsiung 804, Taiwan; E-Mail: michael@mail.nsysu.edu.tw

6 Graduate Institute of Ecology and Evolutionary Biology, China Medical University, Taichung 40402, Taiwan; E-Mail: choumasa@mail.cmu.edu.tw

* Author to whom correspondence should be addressed; E-Mail: ycshen@ntu.edu.tw; Tel.: +886-2-23123456 (ext.62226); Fax: +886-2-23919098.

Received: 13 May 2013; in revised form: 29 May 2013 / Accepted: 30 May 2013 /

Published: 4 June 2013

\begin{abstract}
Three novel C19 homolignans, taiwankadsurins D (1), E (2) and F (4), and two new C18 lignans kadsuphilins $\mathrm{N}$ (3) and O (5) were isolated from the aerial parts of Taiwanese medicinal plant Kadsura philippinensis. The structures of compounds 1-5 were determined by spectroscopic analyses, especially 2D NMR techniques. The structure of compound $\mathbf{5}$ was further confirmed by X-ray crystallographic analysis. Compounds $\mathbf{1}$ and $\mathbf{2}$ have a 3,4-\{1'-[(Z)-2"-methoxy-2"-oxoethylidene $]\}$-pentano(2,3-dihydrobenzo[b]furano)3-(2"'-methoxycarbonyl-2"'-hydroxy-2"',3'-epoxide) skeleton.
\end{abstract}

Keywords: Kadsura philippinensis; taiwankadsurins; lignans 


\section{Introduction}

Kadsura belongs to the family Schisandraceae and it is only distributed in eastern and southern Asia [1]. Species of Kadsura were used in Chinese folk medicine for the treatment of cold, rheumatoid arthritis and gastroenteritis and as an anodyne to relieve pain [2]. The major constituents of Kadsura plants were reported to be bioactive lignans, which possess antitumor, antiviral and anti-hepatitic activities [3-8]. K. philippinensis Elm. is an evergreen vine, mainly distributed at low altitude onremote islands of Taiwan such as Green Island [9]. Our previous phytochemical studies on the EtOAc extracts of $K$. philippinensis resulted in the isolation of two novel triterpene dilactones and many lignans [10-17]. In this paper, we report the isolation and structure elucidation of three new C19 homolignans, named taiwankadsurins D-F, and two new C18 lignans, designated kadsuphilins N and O.

\section{Results and Discussion}

The leaves and stems of $K$. philippinensis were extracted with mixture of $\mathrm{CH}_{2} \mathrm{Cl}_{2}$ and acetone, then suspended in $\mathrm{H}_{2} \mathrm{O}$ and extracted with EtOAc. The EtOAc-soluble part was subjected to extensive chromatography including flash column, normal and reversed-phase HPLC, furnishing compounds 1-5 (Figure 1).

Figure 1. Chemical structures of compounds 1-6.
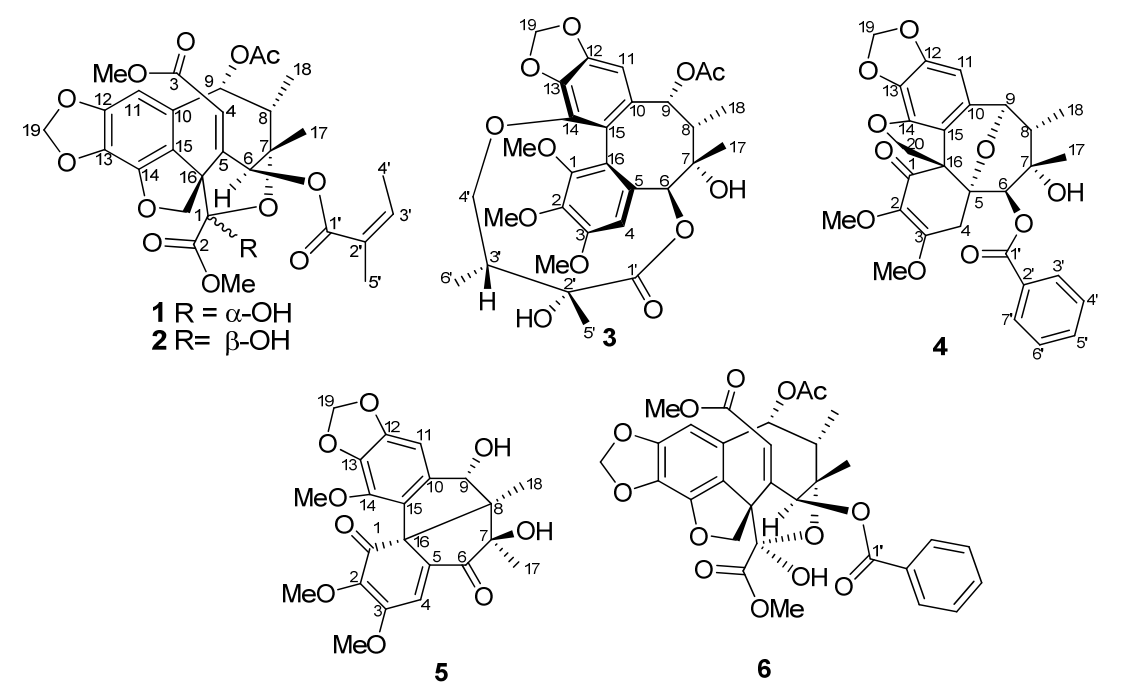

Taiwankadsurin $D(\mathbf{1}),\left([\alpha]_{D}^{25}+57^{\circ}, \mathrm{CH}_{2} \mathrm{Cl}_{2}\right)$ had a molecular formula $\mathrm{C}_{29} \mathrm{H}_{32} \mathrm{O}_{13}$, as derived from its HREIMS at $m / z 611.1735\left([\mathrm{M}+\mathrm{Na}]^{+}\right.$, calcd 611.1741) indicating 14 degrees of unsaturation. The UV absorption $(273,225 \mathrm{~nm})$ and IR bands $\left(1,731,1,721\right.$ and $\left.1,628 \mathrm{~cm}^{-1}\right)$ indicated a benzyl and $\alpha, \beta$, unsaturated ester functionalities. The ${ }^{1} \mathrm{H}-\mathrm{NMR}$ of 1 exhibited two methoxyl singlets $(\delta 3.93,3.59)$, an acetyl singlet $(\delta 2.13)$, two methyl singlets $(\delta 1.31,1.99)$, two methyl doublets $(\delta 1.36, J=6.9 \mathrm{~Hz}$; $\delta 2.05, J=7.2 \mathrm{~Hz}$ ), two oxymethylene protons $(\delta 5.00,4.53$, each $\mathrm{d}, J=10.2 \mathrm{~Hz})$ and two dioxymethylene protons ( $\delta 5.97,5.98$, each s-like). According to ${ }^{13} \mathrm{C}-\mathrm{NMR}$ and DEPT spectra, compound 1 had total 29 signals including seven methyl, two methylene, six methine and fourteen quaternary carbons. Moreover, ${ }^{1} \mathrm{H}-\mathrm{NMR}$ spectroscopic data of $\mathbf{1}$ showed characteristic signals of H-4 $(\delta 5.99), \mathrm{H}-6\left(\delta\right.$ 6.28) and H-9 $(\delta 6.55)$, and ${ }^{13} \mathrm{C}-\mathrm{NMR}$ data of C-1 ( $\left.\delta 97.5 \mathrm{~s}\right), \mathrm{C}-2$ ( $\left.\delta 171.0 \mathrm{~s}\right)$ and C-3 
( $\delta 165.4 \mathrm{~s}$ ) similar to those of taiwankadsurin A (6), suggesting that compound $\mathbf{1}$ is an analogue of the latter [10]. However, a benzoyl group in $\mathbf{6}$ was missing and replaced with an angeloyl group at C-6 in $\mathbf{1}$. Further HMBC correlations (Figure 2) of H-11/C-12, C-13, C-15 and H-20/C-14, C-15, C-16, confirmed that compound 1 possessed a dihydrobenzofuran system. The ethylidene-octane ring was also deduced from the HMBC correlations of H-9/C-7,C-10,C-11,C-15; Me-18/C-7,C-8,C-9; Me-17/ C-6,C-7,C-8 and H-6/C-4,C-5, C-7, C-8. The acetyl and angeloyl groups attaching at C-9 and C-6 respectively, were resulted from the HMBC correlations of H-9 $(\delta 6.55)$ with the acetyl carbonyl, and H-6 $(\delta 6.28)$ with the angeloyl carbonyl. Furthermore, methoxyl groups $\left(\delta_{\mathrm{H}} 3.93, \delta_{\mathrm{H}} 3.59\right)$ attaching at carbonyls C-2 $\left(\delta_{\mathrm{C}} 171.0\right)$ and C-3 $\left(\delta_{\mathrm{C}} 165.4\right)$ were deduced from their mutual HMBC correlations.

It was noted that the dioxygenated tertiary carbon $\mathrm{C}-1$ connected to $\mathrm{C}-7$ through an ether bridge to account for the last degree of unsaturation. The relative configuration of $\mathbf{1}$ was determined by the NOESY experiment and by comparing the NMR data of $\mathbf{1}$ with those of taiwankadsurin A (Figure 2). Assuming that $\mathrm{H}-9$ was $\beta$-oriented due to quite similar NMR spectra of $\mathbf{1}$ and taiwankadsurin A [10], thus, cross peaks between H-4, H-9 and Me-5', and correlation between H-9 and H-8, rather than Me-18 suggested that $\mathrm{H}-8$ and 6- $O$-angeloyl group should be positioned on the $\beta$-face of the molecule. On the other hand, correlation between Me-18(eq) and Me-17(eq) accounted for the $\alpha$-disposition of the ether ring between $\mathrm{C}-1$ and C-7. In addition, NOESY correlation between H-6 and the methoxyl protons at C-2 indicated that H-6 and the hydroxyl group attached at C- 1 are $\alpha$-oriented. On the basis of above findings, the relative configuration of 1 was assigned as $1 \mathrm{R}^{*}, 6 \mathrm{~S}^{*}, 7 \mathrm{~S}^{*}, 8 \mathrm{~S}^{*}, 9 \mathrm{R}^{*}, 16 \mathrm{~S}^{*}$.

Figure 2. Selected HMBC (arrow) and NOESY (double headed arrow) correlations of $\mathbf{1 .}$
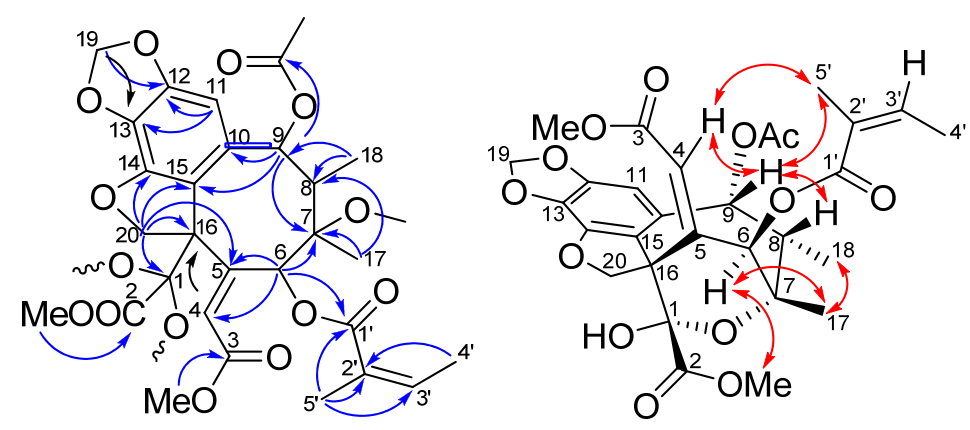

Taiwankadsurin E (2) is an isomer of $\mathbf{1}$ as inferred from the identical molecular weight in HRMS, similar UV and IR absorptions and NMR data. The ${ }^{1} \mathrm{H}-\mathrm{NMR}$ spectrum (Table 1) of $\mathbf{2}$ had the same characteristic peaks with 1 except that H-6 was downfield shifted to $\delta_{\mathrm{H}} 6.91$, while the methoxyl protons at C-2 was upfield shifted to $\delta_{\mathrm{H}} 3.61$. Detail analysis of HMBC correlations of 2 revealed that the locations of angeloyl, acetyl and methoxyl groups were the same as $\mathbf{1}$. The configuration of $\mathbf{2}$ was established from NOESY experiment, in which most of the cross peaks were identical to those of $\mathbf{1}$. However, the correlation between H-6 and the methoxy at C-2 was missing in 2. Therefore, the structure of $\mathbf{2}$ was established, being an 1-epimer of $\mathbf{1}$. 
Table 1. ${ }^{1} \mathrm{H}-\mathrm{NMR}$ data $\left(\mathrm{CDCl}_{3}\right)$ of compounds $\mathbf{1}-\mathbf{5}^{a, b}$.

\begin{tabular}{|c|c|c|c|c|c|}
\hline Position & $\mathbf{1}^{a}$ & $2^{b}$ & $3^{a}$ & $4^{b}$ & $5^{a}$ \\
\hline 4 & 5.99 , brs & $6.06, \mathrm{~d}(2.4)$ & $6.84, \mathrm{~s}$ & $\begin{array}{l}3.08, \mathrm{~d}(18.4) \\
3.17, \mathrm{~d}(18.4)\end{array}$ & $7.34, \mathrm{~s}$ \\
\hline 6 & $6.28, \mathrm{~d}(2.7)$ & $6.69, \mathrm{~d}(2.4)$ & $5.76, \mathrm{~s}$ & $5.42, \mathrm{~s}$ & \\
\hline 8 & $2.23, \mathrm{~m}$ & $2.23, \mathrm{~m}$ & $1.97, \mathrm{~m}$ & $2.00, \mathrm{~m}$ & \\
\hline 9 & $6.55, \mathrm{~d}(2.7)$ & $6.63, \mathrm{~d}(2.8)$ & $5.48, \mathrm{~s}$ & 4.82, brs & $4.87, \mathrm{~d}(12.9)$ \\
\hline 11 & $6.45, \mathrm{~s}$ & $6.44, \mathrm{~s}$ & $6.47, \mathrm{~s}$ & $6.28, \mathrm{~s}$ & $6.71, \mathrm{~s}$ \\
\hline 17 & $1.31, \mathrm{~s}$ & $1.34, \mathrm{~s}$ & $1.37, \mathrm{~s}$ & $0.97, \mathrm{~s}$ & $1.31, \mathrm{~s}$ \\
\hline 18 & $1.04, \mathrm{~d}(6.9)$ & $1.02, \mathrm{~d}(6.8)$ & $1.30, \mathrm{~d}(6.9)$ & $1.36, \mathrm{~d}(7.6)$ & $0.98, \mathrm{~s}$ \\
\hline \multirow{2}{*}{19} & $5.97, \mathrm{~s}$ & $5.93, \mathrm{~s}$ & $5.94, \mathrm{~s}$ & $5.83, \mathrm{~s}$ & $5.90, \mathrm{~d}(1.5)$ \\
\hline & $5.98, \mathrm{~s}$ & $5.94, \mathrm{~s}$ & $6.03, \mathrm{~s}$ & $5.98, \mathrm{~s}$ & $5.91, \mathrm{~d}(1.5)$ \\
\hline \multirow{2}{*}{20} & \multicolumn{3}{|c|}{$4.53, \mathrm{~d}(10.2) 4.59, \mathrm{~d}(10.0)$} & \multicolumn{2}{|l|}{$4.30, \mathrm{~d}(9.6)$} \\
\hline & \multicolumn{2}{|c|}{$5.00, \mathrm{~d}(10.2) 4.98, \mathrm{~d}(10.0)$} & & \multicolumn{2}{|l|}{$4.43, \mathrm{~d}(9.6)$} \\
\hline & \multicolumn{2}{|l|}{$3.46, \mathrm{~s}$} & \\
\hline \multicolumn{3}{|l|}{$\begin{array}{l}\text { OMe-1 } \\
\text { OMe-2 }\end{array}$} & $3.84, \mathrm{~s}$ & $3.66, \mathrm{~s}$ & $3.77, \mathrm{~s}$ \\
\hline OMe-3 & $3.59, \mathrm{~s}$ & $3.58, \mathrm{~s}$ & \multirow[t]{2}{*}{$3.92, \mathrm{~s}$} & \multirow[t]{2}{*}{ 4.07, s } & $4.11, \mathrm{~s}$ \\
\hline \multicolumn{3}{|l|}{ OMe-14 } & & & \multirow[t]{4}{*}{$3.81, \mathrm{~s}$} \\
\hline OAc & $2.13, \mathrm{~s}$ & $2.13, \mathrm{~s}$ & $1.49, \mathrm{~s}$ & & \\
\hline \multicolumn{5}{|l|}{$1^{\prime}$} & \\
\hline \multicolumn{5}{|l|}{$2^{\prime}$} & \\
\hline $3^{\prime}$ & 6.28 , overlap & $6.23, \mathrm{q}(7.2)$ & $1.92, \mathrm{~m}$ & $7.32, \mathrm{~m}$ & \\
\hline $4^{\prime}$ & $2.05, \mathrm{~d}(7.2)$ & $2.06, \mathrm{~d}(7.2)$ & $\begin{array}{l}3.63 \text { dd }(5.0,8.0) \\
4.16, \mathrm{dd}(5.0,8.0)\end{array}$ & $7.35, \mathrm{~m}$ & \\
\hline $5^{\prime}$ & $1.99, \mathrm{~s}$ & $2.00, \mathrm{~s}$ & $1.23, \mathrm{~s}$ & $7.55, \mathrm{~d}(7.2)$ & \\
\hline $6^{\prime}$ & & & $0.96, \mathrm{~d}(7.2)$ & $7.35, \mathrm{~m}$ & \\
\hline $7^{\prime}$ & & & & $7.32, \mathrm{~m}$ & \\
\hline OH-9 & & & & & $4.28, \mathrm{~d}(12.9)$ \\
\hline
\end{tabular}

Kadsuphilin $N(\mathbf{3}),\left([\alpha]_{D}^{26}-2.4, \mathrm{CH}_{2} \mathrm{Cl}_{2}\right)$, had a molecular formula of $\mathrm{C}_{30} \mathrm{H}_{36} \mathrm{O}_{12}$ as deduced from a pseudo-molecular ion $[\mathrm{M}+\mathrm{Na}]^{+}$at $\mathrm{m} / z 611.2107$ in the HRESIMS. The UV absorption bands at 212, 259 and $292 \mathrm{~nm}$ suggested that 1 possessed a biphenyl chromophore. The IR absorption indicated the presence of hydroxyl $\left(3,479 \mathrm{~cm}^{-1}\right)$ and carbonyl $\left(1,738 \mathrm{~cm}^{-1}\right)$ groups. The ${ }^{13} \mathrm{C}-\mathrm{NMR}$ spectroscopic data and DEPT analysis revealed that compound 3 contains 30 carbons, including ten quaternary sp $^{2}$ carbons $\left(\delta_{\mathrm{C}} 121.2,121.7,130.8,132.8,137.5,139.0,141.8,148.6,151.5\right.$ and 152.3), two ester carbons $\left(\delta_{\mathrm{C}} 168.7\right.$ and 172.4), two quaternary $\mathrm{sp}^{3}$ oxygen-bearing carbons $\left(\delta_{\mathrm{C}} 73.8\right.$ and 76.6$)$, two oxygen-bearing methylene carbons $\left(\delta_{\mathrm{C}} 72.4\right.$ and 101.5), two sp ${ }^{2}$ methine carbons $\left(\delta_{\mathrm{C}} 102.5\right.$ and 111.0), two $\mathrm{sp}^{3}$ methine carbons $\left(\delta_{\mathrm{C}} 42.4\right.$ and 44.1$)$, two oxygen-bearing $\mathrm{sp}^{3}$ methine carbons $\left(\delta_{\mathrm{C}} 83.9\right.$ and 86.6), and eight methyl groups $\left(\delta_{\mathrm{C}} 12.8,17.8,20.3,21.4,28.4,56.2,60.5\right.$ and 60.7). The HMBC correlations of H-11/C-9, C-10, C-12, C-13, C-15; H-9/C-10, C-15; H-4/C-2, C-3, C-5, C-6, C-16; H-6/C-5, C-16; Me-17/C-6, C-7, C-8; Me-18/C-7, C-8, C-9 implied that compound 3 indeed possessed a schizandrin type dibenzocyclooctadiene system [16]. Moreover, HMBC correlations of $\mathrm{H}_{2}-19 / \mathrm{C}-12$, C-13; OMe-1/C-1; OMe-2/C-2; OMe-3/C-3 and H-9/ acetyl carbonyl assigned the methylenedioxy group and three methoxyl groups attached to the aromatic ring and an acetyl group at C-9. In addition, 
the ester linkage could be proved by correlations of H-6/C-1'; Me-5'/C-1', C-2', C-3'; Me-6'/C-2', C-3', C-4' and $\mathrm{H}-4^{\prime} / \mathrm{C}-14$. From the above interpretation, the structure of 3 could be established as 9-acetylgomisin D. The configuration was determined by CD spectrum and NOESY experiment. The strong positive Cotton effect at $229 \mathrm{~nm}$ and the negative Cotton effect at $245 \mathrm{~nm}$ assigned the $S$-configuration of the biphenyl system [18]. The NOESY correlations of H-9/H-8, H-11, H-8/Me-17 and H-6/H-4, Me-17(eq) revealed that the cyclooctadiene ring had a twist-boat-chair form and H-8, H-9 and Me-17 were $\beta$-oriented while H-6 and Me-18 were $\alpha$-configuration (Figure 3). The correlations of H-3'/Me-5' and the NMR data were in good agreement with the configuration of ester linkage that was also present in gomisin D [19].

Figure 3. Selected HMBC (arrow) and NOESY (double headed arrow) correlations of 3.

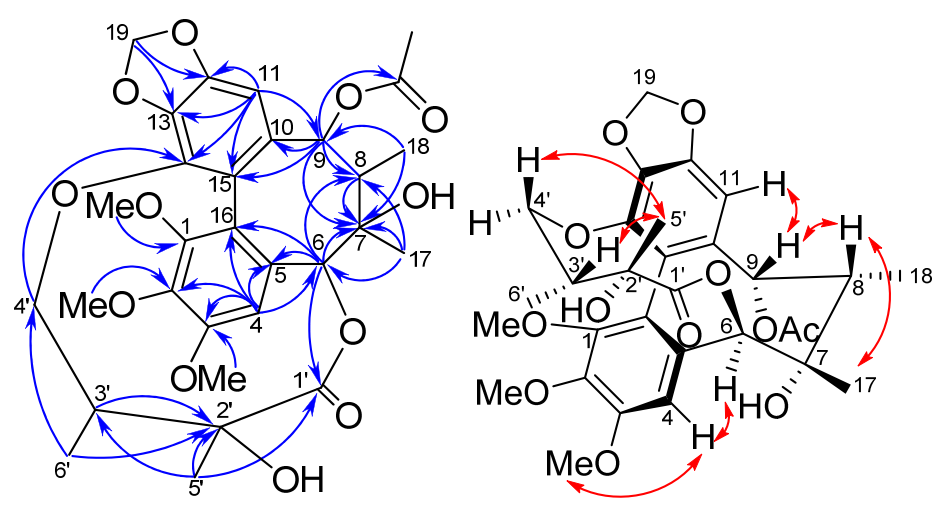

Taiwankadsurin $F(4)$ was isolated as a pale yellow amorphous solid. The molecular formula $\mathrm{C}_{29} \mathrm{H}_{28} \mathrm{O}_{10}$ was deduced from a pseudo-molecular ion at $\mathrm{m} / z$ 559.1580 [M+Na] ${ }^{+}$in HRESIMS. The UV spectrum showed absorptions at $\lambda_{\max } 255,220 \mathrm{~nm}$ and IR bands at $v_{\max } 3,510,1,735,1,725 \mathrm{~cm}^{-1}$ suggested that compound 4 contained phenyl, benzoyl, $\alpha, \beta$-unsaturated ketone and hydroxyl functionalities. The ${ }^{1} \mathrm{H}$ and ${ }^{13} \mathrm{C}-\mathrm{NMR}$ spectroscopic data (Tables 1 and 2) revealed that 4 possessed a substituted cyclohex-2-enone moiety and a spirodihydrobenzofuran ring in a homolignan skeleton similar to kadsuphilol G [14]. The difference could be the angeloyloxy side chain, which was substituted with a benzoyloxy group. This scaffold was supported from HMBC correlations of H-19/ C-12, C-13; H-11/ C-9, C-12, C-13, C-15; Me-18/C-7, C-8, C-9; Me-17/C-6, C-7, C-8; H-4/C-2, C-3, C-5, C-16 and H-20/C-1, C-14, C-15. Moreover, the key HMBC correlations of H-6/ benzoyl carbonyl $\left(\delta_{\mathrm{C}} 165.4\right)$ and $\mathrm{H}-9 / \mathrm{C}-5$ assigned the benzoyl group at C-6. It was found that an ether linkage appeared between C-5 and C-9 due to calculation of double bond equivalence. The relative configuration of 4 was determined by comparing the coupling constants of $\mathbf{4}$ with those of kadsuphilol $\mathrm{G}$ and NOESY experiments. Thus a twist-boat-chair configuration was elucidated on the basis of CD observation, in which a positive Cotton effect was found at $216 \mathrm{~nm}$ and a negative one at $249 \mathrm{~nm}$. The NOESY correlations of H-11/H-8 /H-9 and H-8/ Me-17 suggested that H-8, H-9 Me-17 were all in $\beta$-face while Me-18 was $\alpha$-oriented (Figure 4). Because compound 4 had a TBC-S configuration, the oxygen bridge could be assigned as $\alpha$-disposed. On the basis of the above interpretation, the structure of compound 4 was established and the name taiwankadsurin $\mathrm{F}$ was given. 
Table 2. ${ }^{13} \mathrm{C}-\mathrm{NMR}$ data $\left(\mathrm{CDCl}_{3}\right)$ of compounds $\mathbf{1 - 5}{ }^{a, b}$.

\begin{tabular}{|c|c|c|c|c|c|}
\hline Position & $1^{a}$ & $2^{b}$ & $3^{a}$ & $4^{b}$ & $5^{a}$ \\
\hline 1 & $97.5, \mathrm{C}$ & $97.6, \mathrm{C}$ & $151.5, \mathrm{C}$ & 193.0, C & 196.3, C \\
\hline 2 & 171.0, C & $170.1, \mathrm{C}$ & $141.8, \mathrm{C}$ & $132.5, \mathrm{C}$ & $140.6, \mathrm{C}$ \\
\hline 3 & 165.4, C & $165.5, \mathrm{C}$ & $152.3, \mathrm{C}$ & $157.4, \mathrm{C}$ & $159.0, \mathrm{C}$ \\
\hline 4 & 117.2, CH & $118.3, \mathrm{CH}$ & 111.0, CH & $40.7, \mathrm{CH}_{2}$ & $123.4, \mathrm{CH}$ \\
\hline 5 & $150.5, \mathrm{C}$ & $149.8, \mathrm{C}$ & $130.8, \mathrm{C}$ & 77.6, C & $143.7, \mathrm{C}$ \\
\hline 6 & $72.5, \mathrm{CH}$ & $72.5, \mathrm{CH}$ & $86.6, \mathrm{CH}$ & $77.3, \mathrm{CH}$ & $200.7, \mathrm{C}$ \\
\hline 7 & 79.2, C & 78.4, C & 73.8, C & 72.5, C & $80.7, \mathrm{C}$ \\
\hline 8 & $45.4, \mathrm{CH}$ & $45.5, \mathrm{CH}$ & $44.1, \mathrm{CH}$ & $43.7, \mathrm{CH}$ & $60.4, \mathrm{C}$ \\
\hline 9 & $70.3, \mathrm{CH}$ & $70.2, \mathrm{CH}$ & $83.9, \mathrm{CH}$ & 77.3, $\mathrm{CH}$ & 75.7, $\mathrm{CH}$ \\
\hline 10 & $127.9, \mathrm{C}$ & $127.8, \mathrm{C}$ & $132.8, \mathrm{C}$ & $127.9, \mathrm{C}$ & $144.5, \mathrm{C}$ \\
\hline 11 & 98.7, $\mathrm{CH}$ & $99.9, \mathrm{CH}$ & $102.5, \mathrm{CH}$ & $95.9, \mathrm{CH}$ & $100.4, \mathrm{CH}$ \\
\hline 12 & $150.4, \mathrm{C}$ & $149.8, \mathrm{C}$ & $148.6, \mathrm{C}$ & 151.3, C & 151.2, C \\
\hline 13 & 129.1, C & $128.9, \mathrm{C}$ & 137.5, C & 129.5, C & 136.4, C \\
\hline 14 & 144.9, C & $142.6, \mathrm{C}$ & 139.0, C & $140.9, \mathrm{C}$ & $139.5, \mathrm{C}$ \\
\hline 15 & 118.0, C & $120.5, \mathrm{C}$ & 121.2, C & 121.3, C & $125.7, \mathrm{C}$ \\
\hline 16 & $57.0, \mathrm{C}$ & $58.6, \mathrm{C}$ & $121.7, \mathrm{C}$ & $56.9, \mathrm{C}$ & $69.5, \mathrm{C}$ \\
\hline 17 & $28.2, \mathrm{CH}_{3}$ & $28.5, \mathrm{CH}_{3}$ & $28.4, \mathrm{CH}_{3}$ & 23.1, $\mathrm{CH}_{3}$ & $19.9, \mathrm{CH}_{3}$ \\
\hline 18 & $8.9, \mathrm{CH}_{3}$ & $8.5, \mathrm{CH}_{3}$ & $17.8, \mathrm{CH}_{3}$ & $15.3, \mathrm{CH}_{3}$ & $15.1, \mathrm{CH}_{3}$ \\
\hline 19 & $101.8, \mathrm{CH}_{2}$ & $101.5, \mathrm{CH}_{2}$ & $101.5, \mathrm{CH}_{2}$ & $101.3, \mathrm{CH}_{2}$ & 101.7, $\mathrm{CH}_{2}$ \\
\hline 20 & $80.4, \mathrm{CH}_{2}$ & 78.5, $\mathrm{CH}_{2}$ & & 78.2, $\mathrm{CH}_{2}$ & \\
\hline OMe-1 & & & $60.5, \mathrm{CH}_{3}$ & & \\
\hline OMe-2 & 53.6, $\mathrm{CH}_{3}$ & $54.0, \mathrm{CH}_{3}$ & $60.7, \mathrm{CH}_{3}$ & $60.7, \mathrm{CH}_{3}$ & $60.2, \mathrm{CH}_{3}$ \\
\hline OMe-3 & $51.8, \mathrm{CH}_{3}$ & $51.7, \mathrm{CH}_{3}$ & $56.2, \mathrm{CH}_{3}$ & $58.9, \mathrm{CH}_{3}$ & $58.3, \mathrm{CH}_{3}$ \\
\hline OMe-14 & & & & & $59.4, \mathrm{CH}_{3}$ \\
\hline \multirow{2}{*}{ OAc } & $168.9, \mathrm{C}$ & $168.9, \mathrm{C}$ & 168.7, C & & \\
\hline & 21.0, $\mathrm{CH}_{3}$ & $20.3, \mathrm{CH}_{3}$ & $20.3, \mathrm{CH}_{3}$ & & \\
\hline $1^{\prime}$ & $166.0, \mathrm{C}$ & $166.1, \mathrm{C}$ & $172.4, \mathrm{C}$ & $165.4, \mathrm{C}$ & \\
\hline $2^{\prime}$ & 126.3, C & $126.5, \mathrm{C}$ & 76.6, C & 129.5, C & \\
\hline $3^{\prime}$ & $142.3, \mathrm{CH}$ & $141.7, \mathrm{CH}$ & $42.4, \mathrm{CH}$ & $128.3, \mathrm{CH}$ & \\
\hline $4^{\prime}$ & 16.0, $\mathrm{CH}_{3}$ & $15.9, \mathrm{CH}_{3}$ & $72.4, \mathrm{CH}_{2}$ & $129.7, \mathrm{CH}$ & \\
\hline $5^{\prime}$ & $20.4, \mathrm{CH}_{3}$ & 21.0, $\mathrm{CH}_{3}$ & $21.4, \mathrm{CH}_{3}$ & $133.9, \mathrm{CH}$ & \\
\hline $6^{\prime}$ & & & $12.8, \mathrm{CH}_{3}$ & 129.7, CH & \\
\hline $7^{\prime}$ & & & & $128.3, \mathrm{CH}$ & \\
\hline
\end{tabular}

Figure 4. Selected HMBC (arrow) and NOESY (double headed arrow) correlations of 4.

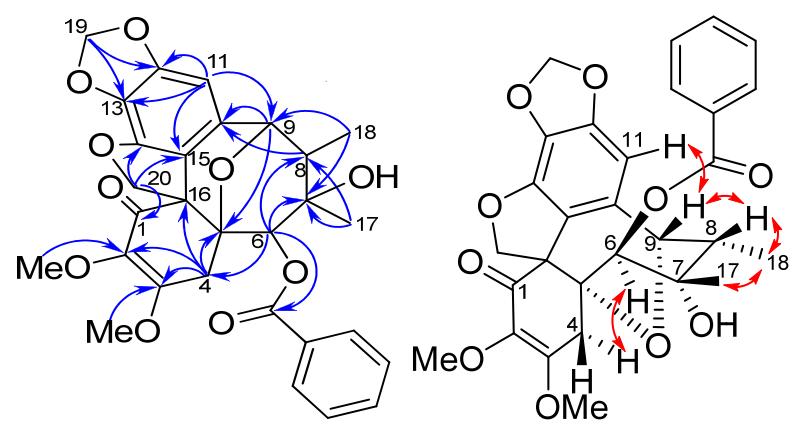


Kadsuphilin $O$ (5) was obtained as pale yellow crystals, with molecular formula $\mathrm{C}_{22} \mathrm{H}_{22} \mathrm{O}_{9}$ as determined by HRESIMS (12 degrees of unsaturation). IR absorption bands at 3,420, 1,716 and $1,620 \mathrm{~cm}^{-1}$ indicated the presence of hydroxyl, carbonyl and aromatic moieties. The ${ }^{1} \mathrm{H}-\mathrm{NMR}$ data (Table 1) and HMQC spectrum showed characteristic signals for two aromatic $\left(\delta_{\mathrm{H}} 6.71,7.34\right)$, one methoxyene-dioxy $\left(\delta_{\mathrm{H}} 5.90,5.91\right.$ as an $\mathrm{AB}$ quartet), one oxygen-bearing methine $\left(\delta_{\mathrm{H}} 4.87\right)$, two tert-methyl $\left(\delta_{\mathrm{H}} 0.98,1.31\right)$ and three methoxyl $\left(\delta_{\mathrm{H}} 3.77,3.81\right.$ and 4.11$)$ protons. A methine doublet at $\delta_{\mathrm{H}} 4.28(\mathrm{~J}=12.9 \mathrm{~Hz})$ revealed the presence of a hydroxy due to no correlation was found in HMQC. ${ }^{13} \mathrm{C}-\mathrm{NMR}$ data and DEPT spectra revealed that compound $\mathbf{5}$ contained five pairs of double bonds $\left(\delta_{\mathrm{C}}\right.$ $100.4,123.4,125.7,136.4,139.5,140.6,143.7,144.5,151.2,159.0)$, two ketone carbonyl carbons $\left(\delta_{\mathrm{C}}\right.$ 196.3 and 200.7$)$ and three quaternary carbons $\left(\delta_{\mathrm{C}} 60.4,69.5,80.7\right)$, one oxygenated methine carbon $\left(\delta_{\mathrm{C}} 75.7\right)$, a methylenedioxy carbon $\left(\delta_{\mathrm{C}} 101.7\right)$, two methyl carbons $\left(\delta_{\mathrm{C}} 15.1\right.$ and 19.9$)$ and three methoxyl carbons $\left(\delta_{\mathrm{C}} 58.3,59.4,60.2\right)$. Thus compound $\mathbf{5}$ possessed five ring systems after deduction of seven double bonds. In the HMBC spectrum, correlations of $\mathrm{H}-11 / \mathrm{C}-9, \mathrm{C}-12, \mathrm{C}-13, \mathrm{C}-14, \mathrm{C}-15$; H-19/C-12, C-13; H-4/C-2, C-3, C-5, C-6, C-16; Me-17/C-6, C-7, C-8; Me-18/C-7, C-8; H-9/C-7, C-15 and C-9-OH/C-9 suggested a dibenzocyclo-octadiene framework with a ketone substituted at the C-6 position. Furthermore, the linkage between C-8 and C-16 was deduced by the correlations of H-9 and Me-18 with $\mathrm{C}-16$, and the remaining ketone group could be assigned to the $\mathrm{C}-1$ position. This finding was further confirmed by comparing the NMR data with those of heteroclitin G [20]. The relative configuration of $\mathbf{5}$ was determined by NOESY correlation and CD. The CD spectrum of $\mathbf{5}$ was similar to that of kadsutherin C [21]. The negative Cotton effect at $240 \mathrm{~nm}$ and the positive Cotton effect at $218 \mathrm{~nm}$ accounted for $S$-configuration for the biphenyl skeleton. Assuming that the $\mathrm{H}-9$ of 5 was in a $\beta$-orientation similar to heteroclitin G, the NOESY correlations of $\mathrm{HO}-9 / \mathrm{Me}-18$ and Me-18/Me-17 indicated that they were on the $\alpha$-face and OH-7 was $\beta$-oriented. Therefore, the configuration of the bipentacyclic ring was established. The structure of $\mathbf{5}$ was finally confirmed by a single-crystal X-ray diffraction analysis, from which a perspective drawing of 5 is provided in Figure 5.

Figure 5. Selected HMBC correlations and X-ray perspective drawing of $\mathbf{5}$.
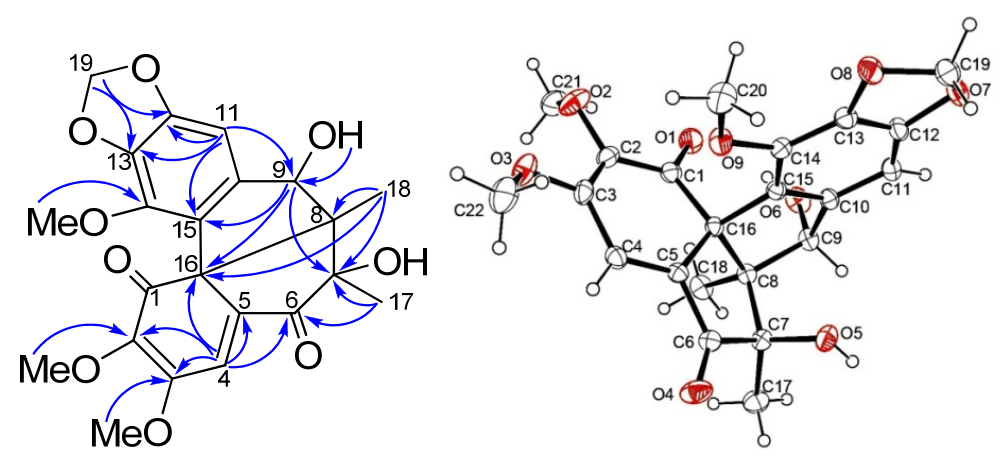

\section{Experimental}

\subsection{General}

Melting points were measured on a Büchi melting point B-540 apparatus and are uncorrected. Optical rotations were recorded on a JASCO DIP-1000 polarimeter. IR and UV spectra were measured on HORIBA FT-720 and U-3210 spectrophotometers, respectively. The ${ }^{1} \mathrm{H}-$ and ${ }^{13} \mathrm{C}-\mathrm{NMR}$, COSY, 
HMQC, HMBC, and NOESY spectra were recorded respectively on a Bruker FT-300 spectrometer $\left(300 \mathrm{MHz}\right.$ for ${ }^{1} \mathrm{H}$ and $75 \mathrm{MHz}$ for ${ }^{13} \mathrm{C}$ ) or on a Bruker AVANCE $400\left(400 \mathrm{MHz}\right.$ for ${ }^{1} \mathrm{H}$ and $100 \mathrm{MHz}$ for ${ }^{13} \mathrm{C}$ ) using TMS as an internal standard. The chemical shifts were given in $\delta$ values (ppm) and coupling constants in Hz. Low-resolution FABMS were recorded on a VG Quattro 5022 mass spectrometer, and HREIMS were measured on a JEOL JMS-SX 102 spectrometer. Silica gel 60 (Merck) was used for column chromatography (CC), and precoated silica gel plates (Merck, Kieselgel $60 \mathrm{~F}-254,1 \mathrm{~mm})$ were used for preparative TLC.

\subsection{Plant Material}

The leaves and stems of $K$. philippinensis were collected at Green Island, Taiwan, in November, 2002. A voucher sample (specimen code: TP 93-2) was deposited at the School of Pharmacy, College of Medicine, National Taiwan University, Taipei, Taiwan.

\subsection{Extraction and Isolation}

K. philippinensis was extracted with mixture of $\mathrm{CH}_{2} \mathrm{Cl}_{2}$ and acetone and partitioned between EtOAc and $\mathrm{H}_{2} \mathrm{O}$ (1:1). The EtOAc-soluble part was subjected to $\mathrm{Si}$ gel column chromatography ( $n$-hexane/EtOAc, 1:0 to 0:1), and after monitoring by ${ }^{1} \mathrm{H}-\mathrm{NMR}$, the middle fraction (fr. 21) was further eluted on LH-20 (MeOH) to give five subfractions (fr.21-1 5). Fr.21-5 was chromatographed on a flash column (Si gel, $n$-hexane/EtOAc, 15:1-0:1) and further separated by normal phase HPLC (n-hexane $\left./ \mathrm{CH}_{2} \mathrm{Cl}_{2} / \mathrm{MeOH}, 35: 65: 1\right)$ to furnish taiwankadsurins $\mathrm{D}(1,13 \mathrm{mg}$ ) and $\mathrm{E}(2,2 \mathrm{mg})$. Kadsuphilin N (3, $14 \mathrm{mg}$ ) was isolated from fr.21-2, which was chromatographed on a flash column (n-hexane/ acetone/EtOAc, 15:1:1 to $1: 1: 1$ ) and further purified with normal phase HPLC ( $n$-hexane $/ \mathrm{CH}_{2} \mathrm{Cl}_{2} / \mathrm{MeOH}, 30: 70: 1$ ) and reverse phase HPLC $\left(\mathrm{MeOH} / \mathrm{H}_{2} \mathrm{O}, 65: 35\right.$ ) alternatively. Fraction fr.21-4 was separated on a Si gel column ( $n$-hexane/EtOAc, 25:1 to 0:1) and a reverse phase HPLC (MeOH/ $\left.\mathrm{H}_{2} \mathrm{O}, 65: 35\right)$ column to yield taiwankadsurin F (4, $\left.4 \mathrm{mg}\right)$ and kadsuphilin $\mathrm{O}(\mathbf{5}, 7 \mathrm{mg})$.

\subsection{Spectroscopic Data}

Taiwankadsurin D (1). $[\alpha]_{D}^{26}+57^{\circ}\left(c 0.5, \mathrm{CH}_{2} \mathrm{Cl}_{2}\right)$; UV $\lambda_{\max }(\mathrm{MeOH}) 225,273 \mathrm{~nm} ; \mathrm{CD}(\mathrm{MeOH}, c=0.2)$ $\mathrm{nm}(\varepsilon) 222(-1.30), 254(+1.27)$; IR (neat) $v_{\max } 3,450,2,938,1,731,1,721,1,628 \mathrm{~cm}^{-1} ;{ }^{1} \mathrm{H}-\mathrm{NMR}$ and ${ }^{13} \mathrm{C}-\mathrm{NMR}\left(\mathrm{CDCl}_{3}, 300 / 75 \mathrm{MHz}\right)$ see Tables 1 and 2, respectively; HRESIMS $m / z$ 611.1735 (calcd for $\left.\mathrm{C}_{29} \mathrm{H}_{32} \mathrm{O}_{13} \mathrm{Na}, 611.1741\right)$.

Taiwankadsurin $E$ (2). $[\alpha]_{D}^{26}-11^{\circ}\left(c \quad 0.2, \mathrm{CH}_{2} \mathrm{Cl}_{2}\right)$; UV $\lambda_{\max }(\mathrm{MeOH}) 233,276 \mathrm{~nm}$; CD (MeOH, $c=0.2) \mathrm{nm}(\varepsilon) 228(-0.78), 247(+0.27)$; IR (neat) $v_{\max } 3,457,1,728,1,717 \mathrm{~cm}^{-1} ;{ }^{1} \mathrm{H}-\mathrm{NMR}$ and ${ }^{13} \mathrm{C}-\mathrm{NMR}\left(\mathrm{CDCl}_{3}, 400 / 100 \mathrm{MHz}\right.$ ) see Tables 1 and 2, respectively; HRESIMS $\mathrm{m} / z$ 611.1737 (calcd for $\left.\mathrm{C}_{29} \mathrm{H}_{32} \mathrm{O}_{13} \mathrm{Na}, 611.1741\right)$.

Kadsuphilin $N(3)$. $[\alpha]_{D}^{25}-2.4^{\circ}\left(c\right.$ 1.3, $\left.\mathrm{CH}_{2} \mathrm{Cl}_{2}\right)$; UV $\lambda_{\max }(\mathrm{MeOH}) 212,259,292 \mathrm{~nm}$; CD (MeOH, $c=0.16) \mathrm{nm}(\varepsilon) 229(+33.56), 245(-2.97), 293(-5.54) ; \mathrm{IR}$ (neat) $v_{\max } 3,479,1,738,1,624$, $1,594 \mathrm{~cm}^{-1} ;{ }^{1} \mathrm{H}-\mathrm{NMR}$ and ${ }^{13} \mathrm{C}-\mathrm{NMR}\left(\mathrm{CDCl}_{3}, 300 / 75 \mathrm{MHz}\right)$ see Tables 1 and 2, respectively; HRESIMS $m / z$ 611.2107 (calcd for $\mathrm{C}_{30} \mathrm{H}_{36} \mathrm{O}_{12} \mathrm{Na}, 611.2104$ ). 
Taiwankadsurin $F(4) .[\alpha]_{D}^{25}-13.2^{\circ}\left(c 0.6, \mathrm{CH}_{2} \mathrm{Cl}_{2}\right)$; UV $\lambda_{\max }(\mathrm{MeOH}) 220,255 \mathrm{~nm}$; $\mathrm{CD}(\mathrm{MeOH}$, $c=0.3) \mathrm{nm}(\varepsilon) 216(+17.34), 249$ (-8.77), $290(-1.53)$; IR (neat) $v_{\max } 3,510,1,735,1,725,1,660$, $1,580 \mathrm{~cm}^{-1} ;{ }^{1} \mathrm{H}-\mathrm{NMR}$ and ${ }^{13} \mathrm{C}-\mathrm{NMR}\left(\mathrm{CDCl}_{3}, 400 / 100 \mathrm{MHz}\right)$, see Tables 1 and 2, respectively; HRESIMS $m / z 559.1573$ (calcd for $\mathrm{C}_{29} \mathrm{H}_{28} \mathrm{O}_{10} \mathrm{Na}, 559.1580$ ).

Kadsuphilin $O(\mathbf{5})$. $[\alpha]_{D}^{25}-8.0^{\circ}\left(c\right.$ 0.6, $\left.\mathrm{CH}_{2} \mathrm{Cl}_{2}\right)$; $\mathrm{MP} 167^{\circ} \mathrm{C}$; $\mathrm{UV} \lambda_{\max }(\mathrm{MeOH}) 215,246,283 \mathrm{~nm}$; $\mathrm{CD}$ $(\mathrm{MeOH}, c=0.22) \mathrm{nm}(\varepsilon) 218(+7.66), 240(-28.11), 282(-6.75)$; IR (neat) $v_{\max } 3,420,1,716$, $1,620 \mathrm{~cm}^{-1} ;{ }^{1} \mathrm{H}-\mathrm{NMR}\left(\mathrm{CDCl}_{3}, 300 \mathrm{MHz}\right)$ and ${ }^{13} \mathrm{C}-\mathrm{NMR}\left(\mathrm{CDCl}_{3}, 75 \mathrm{MHz}\right)$, see Tables 1 and 2, respectively; HRESIMS $m / z 453.1158$ (calcd for $\mathrm{C}_{22} \mathrm{H}_{22} \mathrm{O}_{9} \mathrm{Na}, 453.1161$ ). Crystal data: $\mathrm{C}_{22} \mathrm{H}_{22} \mathrm{O}_{9}$, $M=430.40$, trigonal system, space group $P 2_{1}, a=10.706(2), b=8.218(2), c=10.9345(9) \AA$, $V=960.1(3) \AA^{3}, Z=2, d=1.489 \mathrm{Mg} / \mathrm{cm}^{3}$. A crystal of dimensions $0.60 \times 0.60 \times 0.20 \mathrm{~mm}$ was used for measurements on a RIGAKU AFC7S diffractometer with a graphite monochromator $(\omega-2 \theta$ scans, $2 \theta_{\max }=52.0^{\circ}$ ), Mo K $\alpha$ radiation. The total number of independent reflections measured was 2,134, of which 2026 were observed $\left(|F|^{2} \geq 2 \sigma|F|^{2}\right)$. The crystal structure was solved by the direct method SHELX-86 [22] and expanded using difference Fourier techniques, refined by the program SHEXTL-97 [23] and full-matrix least-squares calculations. Final indices: $R_{f}=0.030, R_{\mathrm{w}}=0.0784$, $w=1 /\left[\sigma^{2}\left(F_{o}{ }^{2}\right)+(0.070 P)^{2}+0.1457 P\right]$, where $\left.P=\left(F_{o}{ }^{2}+2 F_{c}{ }^{2}\right) / 3\right)$. Copies of the deposited crystal data (CCDC 829589) can be obtained, free of charge, from the Cambridge Crystallographic Data Centre, 12 Union Road, Cambridge CB2 1EZ, UK; fax: +44 (0) 1223336033 or E-Mail: deposit@ccdc.cam.ac.uk.

\section{Conclusions}

Phytochemical investigation of the aerial part of Taiwanese Kadsura philippinensis has resulted in isolation of five new lignans 1-5, including three novel C19 homolignans, designated taiwankadsurins D, E and F. Their structures have been established by spectroscopic analyses, especially 2D NMR techniques. In addition, the structure of compound $\mathbf{5}$ was further confirmed by X-ray crystallographic analysis.

\section{Acknowledgments}

This work was supported from the National Science Council of the Republic of China (Grant NSC-98-2320-B-002-027-MY3).

\section{Conflict of Interest}

The authors declare no conflict of interest.

\section{References}

1. Ookawa, N.; Ikeya, Y.; Taguchi, H.; Yosioka. The Constituents of Kadsura Japonica DUNAL. I. The Structures of Three New Lignans, Acetyl-, Angeloyl- and Caproyl-binankadsurin A. Chem. Pharm. Bull. 1981, 29, 123-127.

2. Hu, X.; Zhang, W.K.; Zhu, Q.S. Zhong Hua Ben Cao (in Chinese); Shanghai Scientific \& Techincal Publishers: Shanghai, China, 1999; Volume 2, pp. 912-913. 
3. Charlton, J.L. Antiviral Activity of Lignans. J. Nat. Prod. 1998, 61, 1447-1451.

4. Chang, J.B.; Reiner, J.; Xie, J.G. Progress on the chemistry of dibenzocyclooctadiene lignans. Chem. Rev. 2005, 105, 4581-4609.

5. Wu, M.D.; Huang, R.L.; KuoYang, L.M.; Hung, C.C.; Ong, C.W.; Kuo, Y.H. The Anti-HBsAg (human type B hepatitis, surface antigen) and anti-hbeag (human type B hepatitis, e antigen) $\mathrm{C}_{18}$ dibenzocyclooctadiene lignans from Kadsura matsudai and Schizandra arisanensis. Chem. Pharm. Bull. 2003, 51, 1233-1236.

6. Li, L.N. Biologically active components from traditional Chinese medicines. Pure Appl. Chem. 1998, 70, 547-554.

7. Chen, D.F.; Zhang, S.X.; Kozuka, M.; Sun, Q.Z.; Feng, J.; Wang, Q.; Mukainaka, T.; Nobukuni, Y.; Tokuda, H.; Nishino, H.; et al. Interiotherins C and D, two new lignans from Kadsura interior and antitumor-promoting effects of related neolignans on Epstein-Barr virus activation. J. Nat. Prod. 2002, 65, 1242-1245.

8. Chen, D.F.; Zhang, S.X.; Wang, H.K.; Zhang, S.Y.; Sun, Q.Z.; Cosentino, L.M.; Lee, K.H. Novel Anti-HIV Lancilactone C and Related Triterpenes from Kadsura lancilimba. J. Nat. Prod. 1999, 62, 94-97.

9. Li, H.L.; Chaw, S.M. Schisandraceae-Flora of Taiwan; Epoch: Taipei, Taiwan, 1996; Volume 2, p. 425.

10. Shen, Y.C.; Lin, Y.C.; Kuo, Y.H.; Cheng, Y.B.; Liaw, C.C. Taiwankadsulins A, B and C, three new C-19 Homolignans from Kadsura philippinensis. Org. Lett. 2005, 7, 5297-5300.

11. Shen, Y.C.; Lin, Y.C.; Chiang, M.Y.; Yeh, S.F.; Cheng, Y.B.; Liaw, C.C. Kadsuphilactones A and B, Two New Triterpene Dilactones from Kadsura philippinensis. Org. Lett. 2005, 7, 3307-3310.

12. Shen, Y.C.; Liaw, C.C.; Cheng, Y.B.; Ahmed, A.F.; Lai, M.C.; Liou, S.S.; Wu, T.S.; Kuo, Y.H.; Lin, Y.C.; Khalil, A.T. C-18 Dibenzocyclooctadiene Lignans from Kadsura philippinensis. J. Nat. Prod. 2006, 69, 963-966.

13. Shen, Y.C.; Lin, Y.C.; Ahmed, A.F.; Cheng, Y.B.; Chen, C.T.; Liaw, C.C.; Kuo, Y.H. Four new nonaoxygenated $\mathrm{C}_{18}$ dibenzocylcooctadiene lignans from Kadsura philippinensis. Chem. Pharm. Bull. 2007, 55, 280-283.

14. Shen, Y.C.; Cheng, Y.B.; Lan, T.W.; Liaw, C.C.; Liou, S.S.; Kuo, Y.H.; Khalil, A.T. Kadsuphilols A-H, new oxygenated lignans from Kadsura philippinensis. J. Nat. Prod. 2007, 70, 1139-1145.

15. Shen, Y.C.; Lin, Y.C.; Cheng, Y.B.; Chang, C.J.; Lan, T.W.; Liou, S.S.; Chien, C.T.; Liaw, C.C.; Khalil, A.T. New Oxygenated Lignans from Kadsura philippinensis. Helv. Chim. Acta. 2008, 91 , 483-494.

16. Shen, Y.C.; Lin, Y.C.; Cheng, Y.B.; Chiang, M.Y.; Liou, S.S.; Khalil. A.T. Dibenzocyclooctadiene lignans from Kadsura philippinensis. Phytochemistry 2009, 70, 114-120.

17. Cheng, Y.B.; Lin, Y.C.; Khalil, A.K.; Liou, S.S.; Lee, G.C.; Kuo, Y.H.; Shen, Y.C. Seven new lignan esters from Kadsura philippinensis. Helv. Chim. Acta 2011, 94, 148-158.

18. Liu, J.S.; Li, L. Schisandrins L-O and acetyl schisandrin L from Kadsura coccinea Phytochemistry 1993, 32, 1293-1296.

19. Ikeya, Y.; Taguchi, H.; Yosioka, I.; Iitaka, Y.; Kobayashi, H. The constituents of schizandra chinensis baill. ii. the structure of a new lignan, gomisin d. Chem. Pharm. Bull. 1979, 27, 1395-1401. 
20. Yang, X.W.; Miyashiro, H.; Hattori, M.; Namba, T.; Tezuka, Y.; Kikuchi, T.; Chen, D.F.; Xu, G.J.; Hori, T.; Extine, M.; et al. Isolation of novel lignans, heteroclitins F and G, from the Stems of Kadsura heteroclita, and anti-lipid peroxidative actions of heteroclitins A-G and related compounds in the in vitro Rat Liver Homogenate System. Chem. Pharm. Bull. 1992, 40, $1510-1516$.

21. Lu, Y.; Chen, D.F. Kadsutherins A-C: Three new dibenzocyclooctane lignans from the stems of Kadsura species Helv. Chim. Acta 2006, 89, 895-901.

22. Sheldrick, G.M. SHELXS-86. Program for the solution of crystal structures. University of Göttingen: Göttingen, Germany, 1985.

23. Sheldrick, G.M. SHELXS-97. Program for the solution of crystal structures. University of Göttingen: Göttingen, Germany, 1997.

Sample Availability: Samples of the compounds may not be available from the authors.

(C) 2013 by the authors; licensee MDPI, Basel, Switzerland. This article is an open access article distributed under the terms and conditions of the Creative Commons Attribution license (http://creativecommons.org/licenses/by/3.0/). 